\title{
COMPARATIVE STUDY ON PLANNED REPEAT CAESAREAN SECTION AND UNPLANNED REPEAT CAESAREAN SECTION
}

\author{
NUR $J^{1}$, KHANOM R ${ }^{2}$, AKTER $S^{3}$
}

\begin{abstract}
:
Repeat Caesarean section always carries more risk than first time caesarian delivery. In our country, antenatal care is always neglected. When this negligence occurs during subsequent pregnancy who had already goes on Caesarean section for the first pregnancy. In our study, we try to compare between the planned and unplanned repeat Caesarean section. The study was carried out at Mymensingh Medical College Hospital, Mymensingh and Amina Nursing Home at Charpara Mymensingh. This was a retrospective case control study,

There were 100 patients in Group: A, (Planned repeat Caesarean section), Group B was also consisted with 100 patients (Unplanned repeat Caesarean section). Odd ratio was measured. Odd ratio between group; $A$ and Group: $B$ was 2.8. The two groups were compared by their age and independent $t$ test was carried out.

Group: A. Mean $\pm S D 25.76 \pm 4.461$ Group: B. Mean $\pm S D=26.12 \pm 5.513$. By pair independent $t$ test: $P$ value: $.076^{n s}$. So we can conclude that regular antenatal Check up is mandatory for those whose 1 st delivery was conducted by Caesarean section irrespective of age and economical status.
\end{abstract}

Key Words: Planned repeat Caesarean section. Unplanned repeat Caesarean section. Antenatal Check up.

J Dhaka Med Coll. 2015; 24(1) : 57-61.

\section{Introduction:}

The word woman is derived from womb. The women play critical role in the continuation of human race. They are to suffer a lot through mortality and morbidity in performing the role of maternity. The aim of an obstetrician is to achieve happy outcome; that is, healthy and sound mother and baby. Some of the deliveries get too risky through the natural vaginal route jeopardizing the life or health of the mother or baby. The caesarean section has been playing critically important and effective role in the relevant efforts.

Caesarean section is considered a safe surgical procedure. Better anaesthesia, improved surgical techniques, more efficacious preventive and therapeutic measures against infections and thrombo prophylaxis have contributed to the advancement of safety. Despite this, caesarean section remains associated with higher maternal morbidity and mortality than vaginal delivery ${ }^{1,2}$. Although anaesthesia and surgery carry their inherent risks, maternal morbidity and mortality at caesarean section is more a consequence of either a disease predating pregnancy or induced by pregnancy ${ }^{3}$.

About one-third of performed caesarean sections are repeat procedures [4]. Repeat caesarean sections are associated with an increased incidence $\mathrm{H} / \mathrm{O}$ previous caesarean section, previous of placenta praevia and placenta praevia accreta ${ }^{5-7}$, scar dehiscence and rupture ${ }^{3,8,9}$.

A planned c-section offers some advantages over an unplanned c-section that occurs during labor. For example, there is a lower risk of surgical injuries and of infections. The emotional impact of a cesarean that is planned

1. Dr. Jinnatun Nur, Associate Professor. Community Based Medical College, Mymensingh

2. Dr. Rashida Khanom, Associate professor. Dhaka Medical College Dhaka. FCPS Obs \& Gynae).

3. Dr. Sumaya Akter, Registrar, Popular Medical College Hospital, Dhaka.

Correspondence : Dr. Jinnatun Nur, Associate professor. Community based medical college, Mymensingh. DGO, FCPS (Obs \& Gynae) 01711607192. 
in advance appears to be similar to or only somewhat worse than a vaginal birth. By contrast, unplanned cesareans can take a greater emotional toll. In addition, a woman planning repeat cesarean surgery would almost certainly be less likely to experience difficulty breastfeeding if she had breastfed before or to have negative feelings for her baby compared with a first-time mother having a planned cesarean. Nonetheless, a planned cesarean still involves the risks associated with major surgery. And both planned and unplanned cesareans result in a uterine scar, which increases risk for serious concerns for mothers and babies in future pregnancies, and for adhesion-relation problems in mothers at any time ${ }^{10,11,12}$.

Most studies compare patients delivered by caesarean section with those delivered vaginally. The aim of our study, however, was to evaluate maternal complications during the peripartum period in relation planned repeated Caesarean section and unplanned repeated Caesarean section

\section{Methodology:}

This was a retrospective case control study. The study was done at Mymensingh Medical College Hospital, Mymensingh (Obs \& Gynae dept), and Amina Clinic Charpara, Mymensingh. Sample was collected in purposive sampling method. And all the surgery was performed by the same surgeon (JNE). The study period was from 1 st January 2010 to 31 st December 2010. During this 12 months period 200 patients were selected purposively. In Group A, there were 100 patients but their antenatal check up was regular and they were mentally prepares to do $\mathrm{C} / \mathrm{S}$. And elective $\mathrm{C} / \mathrm{S}$ was done on an average two weeks before EDD. In Group: B there were also 100 patients with repeat $\mathrm{C} / \mathrm{S}$ but the antenatal check up was poor and $\mathrm{C} / \mathrm{S}$ was done on emergency basis due to $\mathrm{H} / \mathrm{O}$ previous $\mathrm{C} / \mathrm{S}$, placenta previa, placenta accreta, CPD, foetus distress etc.

\section{Inclusion criteria:}

All the patient who were perform repeat C/S

\section{Exclusion criteria:}

Patient came with uterine rupture.

Patient with eclampsia or preeclamsia

Uncontrolled Diabetes Mellitus.

Patient were selected in a fashion that demographic profile was not significant between the two groups.

During surgery we took our best effort to keep the tissue adhesion free. There are number of steps that can be taken during abdominal or pelvic surgery to minimize postoperative complications, such as the formation of adhesions. Such techniques and principles may include:

- Handling all tissue with absolute care

- Using powder-free surgical gloves

- Controlling bleeding

- Choosing sutures and implants carefully

- Keeping tissue moist

- Preventing infection

Descriptive statistics were generated and significance of statistical comparison was determined by the chi-squared test. The Fisher exact test was used for smaller groups. Odds ratios (OR) and 95 confidence intervals (CI) were calculated to identify the association between number of caesarean sections and certain complications. $P<0.05$ was considered statistically significant

\section{Result}

Table-I

Age distribution between the two groups:

\begin{tabular}{lcclll}
\hline \multicolumn{3}{c}{ Group: A } & \multicolumn{3}{c}{ Group: B } \\
\hline$<30$ year & 73 & $73 \%$ & $<30$ year & 70 & $70 \%$ \\
31-35 year & 25 & $25 \% \%$ & $31-35$ year & 27 & $27 \%$ \\
$>$ 36 year & 02 & $2 \%$ & $>36$ year & 3 & $3 \%$ \\
\hline Total 100 & $100 \%$ & & 100 & $100 \%$ \\
\hline
\end{tabular}

Group: A. Mean \pm SD $25.76 \pm 4.461$ Group: B. Mean $\pm \mathrm{SD}=26.12 \pm 5.513$

By pair independent $\mathrm{t}$ test: $\mathrm{P}$ value: $.076^{\mathrm{ns}}$ 
Table-II

Duration of surgery

\begin{tabular}{lcc}
\hline Parameter & Group A & Group B \\
\hline$<30 \mathrm{~min}$ & 8 & 4 \\
$30-60 \mathrm{~min}$ & 88 & 84 \\
$>60 \mathrm{~min}$ & 4 & 12 \\
\hline
\end{tabular}

Group: A. Mean $\pm \mathrm{SD}=47.32 \pm 9.593$. Group: B. Mean $\pm \mathrm{SD}=51.44 \pm 10.566$

By pair independent $t$ test: $P$ value: .044

Table-III

Blood loss during surgery:

\begin{tabular}{lccc}
\hline Blood loss & Group: A & Group: B & P Value \\
\hline Average & 96 & 72 & $0.1801^{\mathrm{NS}}$ \\
More than average & 4 & 28 & $0.0001^{\mathrm{S}}$ \\
\hline
\end{tabular}

Table-IV

Blood transfusion during surgery:

\begin{tabular}{lccc}
\hline Amount of bag & Group: A & Group: B & P Value \\
\hline No transfusion & 62 & 30 & $0.0038^{\mathrm{S}}$ \\
1 bags & 20 & 28 & $0.5134^{\mathrm{NS}}$ \\
2 bags & 6 & 12 & $0.3679^{\mathrm{NS}}$ \\
3 bags & 3 & 13 & $0.0439^{\mathrm{S}}$ \\
4 bags & 6 & 9 & $0.6065^{\mathrm{NS}}$ \\
$>$ 4 bags & 4 & 8 & $0.5134^{\mathrm{NS}}$ \\
\hline
\end{tabular}

Table-V

Previous adhesion identified during surgery

\begin{tabular}{lcccc}
\hline Adhesion & Group: A & Group: B & P Value & \\
\hline Yes & 25 & 55 & 80 & $0.001^{\mathrm{S}}$ \\
No & 45 & 75 & 120 & \\
\hline
\end{tabular}

\section{$P$ value and statistical significance:}

Chi squared equals 45.000 with 2 degrees of freedom.

The two-tailed $\mathrm{P}$ value is less than 0.0001

By conventional criteria, this difference is considered to be extremely statistically significant.
Table-VI

Position of placenta during surgery.

\begin{tabular}{lccc}
\hline Placenta & Group: A & Group: B & P value \\
\hline Normally situated & 91 & 85 & $0.9^{\text {NS }}$ \\
Placenta previa & 8 & 13 & \\
Placenta Accreta & 1 & 2 & \\
\hline
\end{tabular}

Table-VII

Need to Uterine ovarian artery legation and Uterine artery legation

Associated surgery Group: A Group: B P Value

\begin{tabular}{llll}
\hline Uterine ovarian & 3 & 5 & $0.78^{\mathrm{NS}}$
\end{tabular}

artery legation

\begin{tabular}{llll} 
Uterine artery legation 6 & 13 & $0.41^{\mathrm{S}}$ \\
\hline
\end{tabular}

Table-VIII

Injury to the urinary bladder during surgery

\begin{tabular}{lccc}
\hline Injury to bladder & Group: A & Group: B & P Value \\
\hline Yes & 2 & 12 & $0.0281^{\mathrm{S}}$ \\
No & 98 & 88 & \\
\hline
\end{tabular}

Table-IX

Emergency Hysterectomy during repeated Caesarean section

\begin{tabular}{lcc}
\hline Associated Hysterectomy & Group: A & Group: B \\
\hline Yes & 2 & 6 \\
No & 98 & 94 \\
\hline
\end{tabular}

By Chi squared test $\mathrm{p}$ value $<0.001$

Table-X

Shows uneventful and eventful surgery between the two groups:

Complication during surgery Group: A Group: B

Uterine ovarian artery legation $3 \quad 5$

$\begin{array}{lll}\text { Uterine artery legation } & 6 & 13\end{array}$

Injury to bladder $\quad 2 \quad 12$

Associated hysterectomy $\quad 2 \quad 6$

Total Complication $\quad 13 \quad 36$ 
Table-XI

Shows the final result of the two groups:

\begin{tabular}{lccc}
\hline & Group: A & Group: B & Total \\
\hline Complication occur & 13 & 36 & 49 \\
Complication not occur & 87 & 64 & 151 \\
\hline Total & 100 & 100 & 200 \\
\hline OR $=3.744$.
\end{tabular}

So unplanned repeat caesarean section is 3.744 times more risky than planned repeat Caesarean section

\section{Discussion:}

Analyzing the age incidence, it has been found that in group: A 73\% and 70\% in group B patient is within < 30 year.

Usually 2130 year's age range is considered to be of most conducive and high fertility. While comparing with other similar studies in the developing countries, we find this age range topping the list in the statistics of repeat caesarean cases. We have studied the dissertations and reports of the following authors wherein we found the similar age incidence result : Faisal ${ }^{13}$,. Fatema ${ }^{14}$, Hasina ${ }^{15}$, Akhtari ${ }^{16}$, . Nibash ${ }^{17}$, Tahamina ${ }^{18}$, Jinnat Shahin ${ }^{19}$, Mishkad ${ }^{20}$, Jaheeda ${ }^{21}$, Nishat ${ }^{22}$. Gulshan ${ }^{23}$,

Patients with ages more than 35 years have the following experiences; In Michael's study the maternal age 35 or more were associated with an increased risk of failure of vaginal delivery ${ }^{24}$. Study has demonstrated that women older than 35 year have higher risk of caesarean delivery. Aaron in his study shared that women older than 40 year who have had a prior caesarean delivery have an almost 3 fold higher risk of unsuccessful vaginal delivery compared to women younger than 40 years ${ }^{25}$

In our study, (Table - II) surgery time was more in unplanned repeat $\mathrm{C} / \mathrm{S}$. In group $\mathrm{A}$ mean duration of surgery was $47.32 \pm 9.593$. In group $B$ it was $51.44 \pm 10.566(\mathrm{p}<0.05)$. So unplanned repeat $\mathrm{C} / \mathrm{S}$ takes more time than planned repeat $\mathrm{C} / \mathrm{S}$. This study is consisted with the study of Akhtari ${ }^{16}$, . Nibash ${ }^{17}$ and Jaheeda ${ }^{21}$.

Analysis revealed that (Table-III) blood transfusion was required for $20 \%$ of patients in group A and 16\% for group B. This is higher than the $3 \%$ reported by Loverro [5]. The group with planned repeat caesarean sections needs fewer blood transfusions, which is mostly due to the fact that these patients had elective deliveries while those with unplanned caesarean section were mostly emergency deliveries.

In table 5, adhesion was less in Group: A and more in Group: $\mathrm{B}(\mathrm{P}<0.001)$. Though we have not taken the history of antenatal check up in first pregnancy, but we can assume that first caesarean sections was also on emergency basis so there was more complication during surgery and more adhesion. This is most probable that the Group: B patient did not take regular antenatal check up. This adhesion causes more complicated repeat caesarean sections

In table VI, position of placenta was not significant between the two groups

In table VII, VIII \& IX shows that the associated surgery during repeat caesarean sections was more in Group: B than the Group: A. Uterine artery ligation was more in Group: B (<0.05\%). Injury to the urinary bladder $(\mathrm{p}=0.0281)$ was significant in Group: B. and the devastating complication hysterectomy were significant in Group: B.

Table XI shows the Odd ratio between the two groups, $\mathrm{OR}=3.744$.

So unplanned repeat caesarean section is 3.744 times more risky than planned repeat Caesarean section

\section{Conclusion:}

The study shows that almost all the caesarean patients have gone through antenatal care, regular or irregular, influencing the outcome positively. Although in most cases it was seen that the patient is brought to the hospital with emergency condition affecting the outcome. And patient needs emergency unplanned repeat Caesarean section suffer more complication than patient needs planned repeat Caesarean section.

\section{References:}

1. Diaz SD et al. Uterine rupture and dehiscences: ten - year review and case - control study. South medical journal, 2002, 95 - 431-5. 
2. Hershkowitz $\mathrm{R}$ et al. One or multiple previous caesarean sections are associated with similar frequency of placenta previa. European journal of obstetrics and gynecology and reproductive biology. 1985, 62:185-8.

3. Infections and disorders of puerperium. In: Cunningham FG et al, eds. Williams obstetrics, 20th edition. Norwalk, Appleton and Lang. 1997: 547

4. Takayama $\mathrm{T}$ et al. Risks Associated with caesarian section in women with placenta previa. Journal of obstetrics and gynecology research,1997, 23: 375-9.

5. Loverro G et al.Maternal complications associated with caeserian section. Journal of perinatal medicine, 2001,29:322-6.

6. Miller DA, Chollet JA,Goodwin TM. Clinical risk factors for placenta previa-placenta accrete. American journal of obstetrics and gynecology, 1997, 177:210-4.

7. Zaki $Z M$ et al.Risk factors and morbidity in patients with placenta previa accreta compaired to placenta previa non accrete. Acta obstetrician et gynaecologica scandi navica 1988,77:391-4.

8. Chazotte C,Cohan WR.Catastrophic complications of previous caesarean section. American journal of obstetrics and gynecology,1990,163:738-42.

9. Waterstone M,Bewley S,Wolfe C.Incidence and predictors of severe obstetric morbidity:casecontrol study. British medical journal,2001,322:1089-94.

10. Guise JM, Eden K, Emeis C, et al. Vaginal birth after cesarean: New insights. Evid Rep Technol Assess (Full Rep). 2010;(191)(191):1-397).

11. Aaronson D, Harlev A, Sheiner E, Levy A. Trial of labor after cesarean section in twin pregnancies: Maternal and neonatal safety. $J$ Matern Fetal Neonatal Med. 2010;23(6):550-554.

12. Bujold E, Goyet M, Marcoux S, et al. The role of uterine closure in the risk of uterine rupture. Obstet Gynecol. 2010;116(1):43-50.
13. Faisal A, study of caesarean section in peripheral medical college hospitals. BCPS, Dhaka.

14. Fatema K, History of two previous caesarean section - Patient profile and pregnancy outcome, 1996. BCPS, Dhaka.

15. Hasina A, Evaluation of Hundred cases of caesarean section in Rajshahi Medical College Hospital, 1999. BCPS, Dhaka.

16. Akhtari K, Study of clinical profile with complications of caesarean section in BSMMU, 2000. BCPS, Dhaka.

17. Nibash C P, Study on complications of caesarean section in $\mathrm{SOMCH}, 2004$. BCPS, Dhaka.

18. Tahamina A, Prosprctive clinical study on caesarean deliveries in Dhaka Medical College Hospital, Sir Salimullah Medical College \& Mitford Hospital, 2004. BCPS, Dhaka.

19. Jinnat SC, Analysis of recent trend in the management of patients with history of previous one caesarean section, 2006. BCPS, Dhaka.

20. Mishkad SJ, Evaluation of per operative findings $\&$ postoperative outcome in history of previous caesarean section, cases: study in a peripheral hospital, 2006. BSPS, Dhaka.

21. Jaheeda A, Evaluation of Hundred cases of caesarean section in Shaheed Suhrawardi Hospital, Dhaka, 2006. BCPS, Dhaka.

22. Nishat I, A Study of preoperative \& postoperative complications of caesarean section in MCHTI, Azimpur, Dhaka, 2007. BCPS, Dhaka.

23. Gulshan KN, Clinical study on 100 cases of previous caesarean section in Sir Salimullah Medical College and Mitford Hospital, Dhaka, 2004. BCPS, Dhaka.

24. Michael F, Green MD, -Vaginal delivery after caesarean section-Is the risk acceptable? The New England Journal of Medicine, vol 345:54-55, July 5, 2001, no. 1

25. Aaron B Cauchy, Stephanie Mann, MD, - Vaginal birth after caesarean section delivery: e-medicine, August 9, 2001. 